\title{
AN OLD EROSION SURFACE IN IDAHO: IS IT EOCENE?
}

\author{
JoH N L. RICH.
}

The value of physiography as a means of determining recent earth history in a region where satisfactory sedimentary records are lacking needs no elaboration. Recently physiography is coming to be used as a means of dating ore deposits and in the elucidation of problems of secondary enrichment. If, however, topographic surfaces or peneplains are to be used in correlation, their correct dating becomes a matter of the greatest importance, and the evidence on which the dating is based cannot be too closely scrutinized.

Of late several papers ${ }^{1}$ by Joseph B. Umpleby and W. W.

1 Umpleby, Joseph B., "Geology and Ore Deposits of Republic Mining District, Washington," Wash. Geol. Surv., Bull. No. I, I9Io.

"An Old Erosion Surface in Idaho; Its Age and Value as a Datum Plane," Jour. Geol., Vol. XX., No. 2, pp. I39-147, I912.

"An Old Erosion Surface in Eastern Utah; Its Age and Value in Time Determination," Abstract, Wash. Acad. Sci. Jour., Vol. 2, pp. Iog-I Io, I9I2. (This is practically a restatement of the material given more fully in the preceding reference.)

"Geology and Ore Deposits of Lemhi County, Idaho," U. S. Geol. Survey, Bull. 528, I9I3.

"A Preliminary Account of the Ore Deposits of the Loon Creek District, Idaho," U. S. Geol. Survey, Bull. 530, pp. 67-68, I913. ("The area is a part of that broad region known as the Salmon River Mountains and preserves upon its highest parts the Eocene erosion surface from which those mountains were carved. These remnants constitute the most significant geologic datum plane in the region.")

“Some Ore Deposits in Northwestern Custer County, Idaho," U. S. Geol. Survey, Bull. 539, 1913.

"The Old Erosion Surface in Idaho," Jour. Geol., Vol. XXI., 1913, pp. 224-23I.

"Ore Deposits in the Sawtooth Quadrangle, Blaine and Custer Counties, Idaho," U. S. Geol. Survey, Bull. 580, pp. 22I-249, I9I4.

Atwood, Wallace W., "The Physiographic Conditions at Butte, Montana, 
Atwood have appeared in the journals and in Geological Survey reports in which an old erosion surface, or peneplain, recognized by various writers over large parts of western Montana, northern Idaho, and eastern Washington, is definitely referred to the Eocene and is offered as a valuable datum plane in a region where time relations are otherwise obscure. This datum is used in determining the date of the mineralization of certain ore deposits of Idaho, and the date of copper enrichment in the Butte district.

In view of the voluminous literature based on what is probably an erroneous determination of the age of the summit peneplain of eastern United States, it behooves physiographers to examine carefully the evidence offered in support of the definite dating of another similar widespread erosion surface. Inasmuch as the Eocene age of this peneplain has been questioned, ${ }^{2}$ a reexamination of the evidence seems to be imperative.

SUMMARY STATEMENT OF THE PHYSIOGRAPHIC HISTORY OF THE NORTHERN ROCKY MOUNTAIN REGION, ACCORDING TO UMPLEBY AND ATWOOD.

Briefly stated, the physiographic history of the northern Rocky Mountain region as interpreted by "Umpleby and Atwood has been as follows:

After intense deformation and mountain building at the close of the Cretaceous, a long period of quiet ensued, during which the region was reduced to slight relief. This old erosion surface is thought to have been completed during Eocene time, and is, therefore, called an Eocene erosion surface or peneplain. About the close of the Eocene, this peneplain was uplifted, deformed sufficiently to block out the main drainage lines, and was then and Bingham Canyon, Utah, when the Copper Ores in These Districts were Enriched," Economic Geol., Vol. XI., pp. 697-740, I9I6.

Atwood, W. W., "Physiographic Conditions and Copper Enrichment," Economic Geot., Vol. XII., pp. 545-547, I9I7. (A reply to criticism by Blackwelder.)

2 Blackwelder, E., Jour. Geol., Vol. XX., pp. 4I0-414, I9I2; Econ. Geol., Vol. XII., pp. 54I-545, I9I7. 
dissected by streams until broad valleys, 5 to I 5 or more miles in width and 3,000 to 5,000 feet deep, were developed-presumably during the Oligocene epoch. Lakes whose shore lines may still be recognized were formed in these broad valleys and lacustrine and volcanic sediments accumulated to depths ranging up to several thousand feet, probably under conditions of semiaridity at a time when the region had no direct drainage to the sea. Later, by stream capture, the region became opened to outside drainage and the basin deposits were dissected to their present condition. Umpleby maintains that Miocene and later eruptive rocks, also, were poured out into these valleys, nearly or quite filling them in places.

The argument for the Eocene age of the peneplain is that the Miocene "lake" sediments, and lavas also supposed to be Miocene, lie in intermont basins or valleys cut after the completion of the peneplain. That the basins could not have been formed previous to the peneplanation is thought to be proven by the presence of the shore lines of the Miocene lakes within the basins.

If the basins were formed after the peneplanation, and if Miocene shore lines still exist round the margins of the Miocene sediments within the basins, there seems to be no escape from the conclusion that the peneplain is Eocene. But, does the published evidence support these postulates? For the critical evidence the original reports must be examined. These are: Umpleby's report on the Republic District; the report on the Ore Deposits of Lemhi County, Idaho, and similar reports on adjacent or nearby regions; and Atwood's report on the Butte district.

Examination of Evidence of Eocene Age of Old Erosion Surface, Republic Mining District, Washington. ${ }^{3}$-The Republic Mining District is located in northeastern Washington, near the International Boundary. It is a rugged region, but the summits rise to a more or less uniform altitude.

After mentioning the general accordance of the mountain summits which suggests an old erosion surface, Umpleby dates

${ }^{3}$ Wash. Geol. Surv., Bull. No. I, Igro. 
this surface as Eocene, following Dawson ${ }^{4}$ who has assumed an Eocene age for a similar surface in the interior Plateau of Canada. ${ }^{5}$

As proof of Eocene age:

The early Miocene deposits of the Republic area lie in a great valley which was cut in the Eocene peneplain by a late Eocene or early Miocene river. ... From this relation it is obvious that the peneplain surface is pre-Miocene, and from the fact that the early Miocene beds lie unconformable above earlier Tertiary lavas occur in a deep, steep-sided valley, it seems altogether probable that the peneplain is Eocene.

Umpleby begins with the assumption that the peneplain is Eocene, and follows this by the further assumption that the basins in which the Miocene sediments lie were cut by erosion in this upland surface since its formation. This second assumption is then used to prove the first.

The possibilities suggested by Blackwelder, ${ }^{6}$ namely, that the Miocene sediments may have been faulted or bowed down among older rocks previous to the peneplanation, or may have been deposited in basins which were filled before the peneplanation but in some way came to lie below grade level at the time of peneplanation, are not eliminated or even seriously considered. Inasmuch as the field relations described by Umpleby seem to fit in more readily with Blackwelder's interpretation than with Umpleby's, the unproved assumption that the basins are younger than the peneplain can have no critical value.

On page I9 is the following statement:

The Tertiary beds occupy a deep, broad valley cut in the older rocks after the elevation of the Eocene peneplain.

The evidence cited in support of this is the arrangement of the Tertiary sediments in long narrow belts and the fact that they rest against older rocks through a considerable vertical range

4 Dawson, G. M., "On the Physiographic Geology of the Rocky Mountain Region in Canada, etc.," Trans. Roy. Soc. Canada, I89o, Sec. IV., pp. I-74.

'In a recent report on the geology of a portion of the Interior Plateau ("The Beaverdell Map Area," Geol. Surv. Can., No. 65, Geol. Series, 1915). Reinecke assigns the peneplanation to the late Pliocene.

${ }^{\prime}$ Jour. Geol., Vol. XX., p. 4II, $19 \mathrm{I} 2$. 
as if deposited in steep-sided valleys. The possibility of faulting is mentioned, but it is stated that there is no direct evidence of it, and yet the structure section accompanying the geological map shows relations which might be explained much more readily by faulting than by deposition in a steep-sided valley.

The field relations described elsewhere in the report do not seem to bear out the interpretation of the troughs as post-peneplain erosion valleys. For example: The lava flows and dacite conglomerates at the base of the Tertiaries in the basin have dips of from 15 to 80 degrees in various directions.

The formation is folded, but very much less intensely than the Paleozoic. ...

Overlying the dacite conglomerates and unconformable with them, being very much less deformed, are Miocene "lake beds" in part thinly laminated, having a dip to the east of about $23^{\circ}$ (p. 24).

In an attempt to harmonize the steep dips and the rather intense folding of the Tertiary sediments and lavas with the theory that they were deposited in a valley developed by erosion in a peneplain whose surface is still essentially undisturbed, Umpleby makes the following statement :

The degree of folding which the dacite flow conglomerate possesses and which is vastly more than that of the Eocene peneplain might be thought to signify a pre-Eocene age. On the other hand, its known exposures, except along the ore zone where elevated by later intrusions, are all near the bottom of an Oligocene stream valley, and therefore must be younger than the Eocene.

Note the use of the assumption that the peneplain is Eocene, and the further assumption that the basins are later than the peneplain, and, therefore, must be Oligocene.

To account for the observed facts of distribution and position of the Tertiary beds on the basis of an Eocene age of the summit peneplain, the following series of events must be postulated: first, peneplanation in the Eocene; second, the erosion of a long trough-like valley 5 miles or more in width and several thousand feet deep; third, the deposition of dacite conglomerate and dacite 
flows in this valley; fourth, the rather strong folding of these flows within the valley, yielding dips that must have ranged at least up to 57 degrees $\left(80^{\circ}-23^{\circ}\right)$ and throwing the dacite conglomerates into well-marked anticlines and synclines as described; fifth, the erosion of these folded sediments within the valley; sixth, the deposition, unconformably upon them, of thinly laminated lake beds which must, from their nature, have been deposited nearly horizontally; seventh, the tilting of these lake beds to the east at an angle of about $23^{\circ}$, and finally, the dissection of the whole to the present condition.

Bearing in mind that, according to Umpleby's theory, all these events must have taken place in an erosion valley carved in an Eocene peneplain which is still recognizable and only slightly deformed, one may judge the validity of the evidence for the Eocene age of the peneplain in this district.

Lemhi County, Idaho. ${ }^{7}$-If the evidence from the Republic District fails to prove the Eocene age of the peneplain, what of that from Lemhi County, Idaho, which, with the Republic District, formed the basis of Umpleby's paper on "An Old Erosion Surface in Idaho: Its Age and Value as Datum Plane"? Is the evidence from Lemhi County more convincing on the two critical points of the discussion - the relative ages of basins and peneplain, and the Miocene shore lines within the basins?

The principal geographic features of the county are indicated on the accompanying sketch map (Fig. 26). They are the mountains, the two intermontane troughs, and the valley of Salmon River.

The old erosion surface into which the present topography is carved is correlated with similar surfaces which have been mentioned by numerous workers in surrounding districts. The upland surface, of which considerable flat remnants are still preserved in places, has a general elevation of 8,500 feet, but here and there rises as much as 2,000 feet higher. As to the nature of the surface:

${ }^{7}$ U. S. Geol. Survey, Bull. 528, 1913.

${ }^{8}$ Loc. cit. 


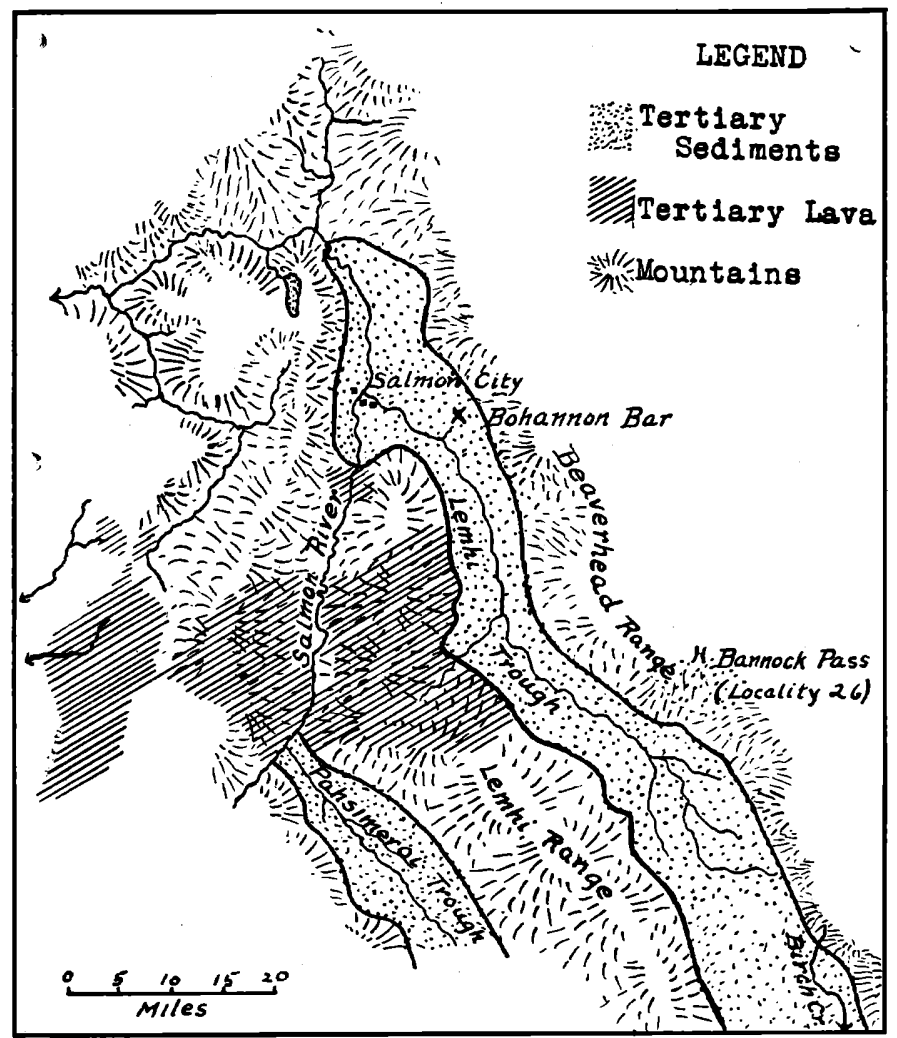

FIG. 26. Sketch map of Lemhi County, Idaho, after Umpleby, U. S. G. S. Bull. 528. Stippled areas are flat-bottomed intermontane troughs. The remainder of the area is mountainous, with the streams in narrow canyon-like valleys.

Were the flat-topped divides of the area used to determine a plane it. would be found to record minor flexures, some faulting, and a broad anticline extending east and west through the Texas District. Such a plane, however, would probably prove much more nearly level than the structure of the Miocene lake beds would indicate.

As to the dating of the plane, we find the following:

In Canada and eastern Washington the surface has been recognized as Eocene and assigned to the same epoch as that in Lemhi County, which in turn is continuous with the west-central Idaho and Clearwater Mountain areas. The other localities mentioned above presumably pre- 
sent the same surface, a deduction resulting from considerations outlined in the next section.

These considerations are:

Sediments assigned to the Miocene on fossil evidence occupy a broad erosion valley developed after the area had assumed its present elevation. Obviously, the old erosion surface is pre-Miocene (p. 26).

What is the proof that the "broad erosion valley" was developed after the peneplain? Umpleby reaches this conclusion by a process of elimination. Of the three possibilities, erosion, down-folding, and down-faulting, erosion is believed to be responsible. Down-folding is rejected because of lack of direct evidence and the fact that the basins lie athwart the structure axes of the region. The possibility of faulting is considered, but is disposed of in the following way:

If, however, the valleys are due to down-faulting they must have been blocked out prior to the deposition of the lake beds and after the elevation of the Eocene surface, for the lake which occupied the Lemhi Valley is shown by its shore line to have stood at its maximum 2,800 feet beneath the plateau surface (p. $3^{6}$ ).

Thus, even if the valleys are due to faulting it does not invalidate the conclusion concerning the age of the Eocene erosion surface.

The present upper limit of the Miocene sediments is taken by Umpleby to mark approximately the elevation of the Miocene shore line in the basin, because:

The elevation to which the lake beds lap up on the older rocks is essentially the same on the narrow and on the wide divides between streams which cross the contact-an accordance which, as the rocks are of diverse resistance to denuding processes, should not prevail if the upper littoral deposits have been greatly eroded at these places.

Another reason for believing that this is approximately the old shore line is that:

In the vicinity of the divide between Lemhi River and Birch Creek, where even in the central portion of the valley the Miocene deposits are but slightly trenched, the marginal lake beds are essentially the same distance (2,800 feet) beneath the plateau level as at Salmon City, where present streams have cut into them to a depth of 1,800 feet. $^{9}$

- In the description of certain of the mines of this region the Miocene beds are said to be in contact with the older rocks on the east side of the basin by a fault with a displacement of at least 300 feet. 
Any determination of the level of the Miocene shore line on the basis of the present upper limit of the Miocene sediments seems to be completely vitiated by the structural relations of those sediments to the basins in which they lie. Thus, near the eastern edge of the Lemhi basin:

On Bohannon Bar placer workings have exposed the eroded edges of the beds for about two miles, and throughout they show a uniform dip of $20^{\circ}$ to $22^{\circ} \mathrm{E}$. As a hasty traverse failed to reveal duplication by faulting, it is supposed that about 4,000 feet of beds are present in this exposure (p. 35).

That is, the beds are dipping at an angle of 20 or 22 degrees toward the base of the mountains which constitute the eastern border of the basin, and about 4,000 feet of them are there exposed. Yet it is in this vicinity that the present upper limits of the sediments at the base of the mountains is taken to represent the Miocene shore line.

The beveling of the sediments by the present surface furnishes the clearest possible proof that the present upper limit of the sediments is an erosion surface developed subsequent to their deformation.

Thus, the critical argument for the Eocene age of the peneplain and against the pre-peneplain age of the basins, namely, the supposed Miocene shore lines, is wholly unconvincing.

Not only is there no convincing proof that the basins are younger than the peneplain, but the structural relations of the beds within the basins militates strongly against such a supposition.

Of the structure of the Miocene beds Umpleby writes:

The beds dip in various directions but generally away from northsouth axes. About Salmon they incline $20^{\circ}$ to $25^{\circ} \mathrm{E}$. along both the east and west side of the basin, but toward its center they incline north or south.

Thus, not only are the beds in these basins greatly deformed in a direction parallel to the basins, but they are also deformed along axes crossing the basins approximately at right angles.

If we are to accept Umpleby's conclusion that the valleys are 
later than the peneplain we must be prepared to explain how a peneplain could have survived, without significant modification, earth movements which so greatly deformed sedimentary beds in an erosion valley cut beneath its surface.

As further evidence of the Eocene age of the upland surface, Umpleby describes "Tertiary" lavas which extend in a belt nearly across the county. Of these he writes:

These lavas occupy summits and valleys, Salmon Canyon being cut in them most of the way from Salmon up to the mouth of Pahsimeroi River, and the highest summits on either side being capped by them (p. 47).

Then comes the following statement:

All the lavas occupy valleys developed after the elevation of the Eocene erosion surface, ... (p. 48).

The geologic and topographic map accompanying the report seems to indicate clearly that these lavas form an integral part of the rock basement into which the present topography is incised. (See Fig. 26.) Moreover, the old erosion surface of supposed Eocene age is as well developed, with as large flat areas on the summits, across the supposedly Miocene lavas as it is elsewhere, and at the same levels. Very possibly those lavas were originally deposited in valleys, but that those valleys were carved by erosion in a peneplain surface which is as well developed upon them as elsewhere is not easy to conceive.

There are at least two lines of purely physiographic evidence which do not harmonize with the idea that the basins are younger than the peneplain.

The course of Salmon River with respect to the basins is significant. After emerging from a mountain canyon the river enters the northwestern end of the Pahsimeroi trough, crosses it, and again enters the mountains through which for a distance of 25 miles it flows in a wild, narrow canyon cut in resistant rocks. On leaving this canyon it enters the northern part of the Lemhi trough, here about I3 miles wide, follows it northward for about 20 miles to its extreme northern end, and enters a sharp, narrow canyon so rugged that for much of its length it is 
practically impassable. In this canyon it flows about 250 miles to the border of the plateau region. Tributaries of the canyon have dissected the upland to early maturity or maturity, making everywhere an exceedingly rugged region with narrow, $\mathrm{V}$-shaped valleys.

Thus it appears that there is an absolute lack of physiographic harmony between the course of Salmon River through these basins and its course elsewhere in the plateau, and this, as Umpleby is careful to state, is not explainable by differences in rock resistance.

If the broad basins were excavated in the old erosion surface by rivers, why did the rivers desert them, and how, in the span of a single cycle, did they gain their courses across the mountain barriers from one basin to another? The rocks in which the narrow, canyon-like portions of the river valley are cut are of the same kind as those in which the wide basins lie. Here is Umpleby's explanation:

The valleys now partly filled by Miocene sediments were undoubtedly formed by rivers which flowed southward and joined Snake River. . . . These relations prevailed until erosion began to operate on the lake beds, * when the head of the basin was tapped by Salmon River. Since then the drainage has been to the north and west. The explanation of the restricted valley occupied Salmon River from a few miles above Salmon nearly to the entrance of the Pahsimeroi is not altogether clear but probably is to be explained by headward erosion ( $p .3^{0}$ ).

This theory involves what is probably a physiographic impossibility. Granting that Salmon River, gnawing headward $25^{\circ}$ miles through the resistant rocks of the plateau, was able to tap the northern end of Lemhi Valley, how is it possible that further headward gnawing of the river, instead of following the weak Miocene sediments of the valley, should have developed a canyon 3,500 feet deep and 25 miles long to the Pahsimeroi basin, and, after tapping that, instead of following it, should have turned again into the resistant rocks, only to repeat the process with respect to other basins farther up stream? Such a theory is difficult to reconcile with the principles governing stream capture.

If, however, the broad basins were formed and filled previous 
to the peneplanation, and if Salmon River gained its present course on the surface of the peneplain, its relation to the basins is readily explained by superposition.

The great width of the Miocene lake basins is further evidence against their formation in the present cycle. From all descriptions it appears that, except where by chance they occupy portions of the broad basins, all the rivers of the plateau region have narrow, $\mathrm{V}$-shaped valleys. Only exceptionally are there valley flats. The Miocene basins, on the other hand, from 5 to 15 miles in width, if produced by river erosion, imply an old-age stage in the cycle. If, as Umpleby contends, these valleys belong to the present cycle, and, as he states, they are not determined by belts of weaker rock, what were the other streams of the region doing while these broad valleys were developing? Are we to believe that in the same length of time they were able to cut only narrow, $\mathrm{V}$-shaped canyons, or that the plateau should have remained undissected?

In reports on northwestern Custer County, Idaho, and on the Sawtooth quadrangle, the old erosion surface is described but no new evidence vital to our problem is produced. In both regions Tertiary lavas are described which are believed to occupy old erosion valleys cut in the peneplain, but in both, as in Lemhi County, the peneplain seems to be as well developed across the lava areas as elsewhere.

The Butte District, Montana. ${ }^{10}$ - In the latest and most elaborate paper dealing with the physiography of the Idaho-Montana District, Atwood describes for the Butte District physiographic features essentially the same as those reported by Umpleby for the region farther west, and interprets them in practically the same way.

The physiographic conditions in the Butte District seem to differ from those of eastern Idaho only in that the intermontane troughs are relatively more numerous and extensive, and that remnants of the old erosion surface are more scattered. The intermontane troughs are floored with deformed Miocene sedi10 Econ. GEol., Vol. XI., pp. 697-740, I916. 
ments which show by their distribution that they are only remnants of former much more extensive deposits.

In dating the various physiographic features, Atwood describes Oligocene and Miocene basin fillings, then:

As the troughs in which these sediments rest were used as drainage lines during the cycle of erosion just preceding the period of filling, and following the uplift and deformation of the summit peneplain, the development of those troughs and of the associated valleys must have been accomplished during late Eocene or early Oligocene time. From this evidence it is clear that the summit peneplain was developed after the close of Cretaceous time, and before the close of Eocene time (p. 712).

Note that the entire argument for Eocene age is based on the unproved assumption that the basins were developed after the uplift and deformation of the summit peneplain.

The argument for the dating of the peneplain is the same as that offered by Umpleby, and is open to the same objections. No proof is offered that the basins may not antedate the peneplain.

The field relations described by Atwood and the series of events which they imply not only fail to yield convincing proofs that the basins are younger than the peneplain but they are so difficult to harmonize with that interpretation that it cannot be accepted without the best of proof.

The following arguments, though they involve a matter of judgment, and, therefore, may not seem conclusive, indicate that the basins are older than the peneplain, rather than younger.

If the basins were cut in the peneplain since its completion, could the latter reasonably be expected to have survived the events recorded in the history of the basins?

If the basins were produced by faulting, and if Atwood's dating is correct, the existing remnants of the peneplain must have survived and maintained their moderately uniform level over the entire district in spite of the following events: (I) shattering by faulting so extensive that nearly one third of the entire area was dropped down some thousands of feet; (2) a long period of aggradation during which the basins were filled to depths of hundreds, and even thousands of feet by materials said to have been 
derived largely from the adjacent mountains; (3) a period of deformation and mountain growth during which the Bozeman beds were deformed and given dips of 15 or more degrees in various places and uplifted in some places 1,000 to 2,000 feet by faulting; (4) a period of dissection, still in progress, during which large portions of the basin fillings were swept away.

If, on the other hand, as one might judge from Atwood's description, the intermontane basins were developed mainly by stream erosion following an outlining of the drainage courses by faulting, there is presented the physiographic anomaly of peneplain remnants surviving dissection to a stage of the cycle sufficiently advanced for the formation of broad, comparatively flat-bottomed basins, 5 to 15 or more miles wide. Such basins could have developed only in a cycle carried to the old-age stage, and in the course of such old-age development it is very doubtful if any considerable peneplain remnants could have survived. Not only that, but these basins are said to be independent of the control of weak rock masses. Here is a further anomaly, for selective erosion may be counted on to have reduced the weaker rocks long before the attainment of old age. Any broad basins formed in this way should show the closest sympathy with the resistance of the rocks. As a matter of fact there seem to be good-sized remnants of the peneplain preserved even on such weak rocks as the Cretaceous and Laramie shales and sandstones (Three Forks folio, Montana).

Even if it be granted that, in spite of these anomalies, the basins might have been developed without the complete destruction of the peneplain, there still remains the long period, occupied by the filling of the basins and by the subsequent removal of a large part of this filling, during which the peneplain must have been undergoing continuous dissection. According to Atwood's map (Fig. 52, p. 710) the Bozeman beds, at their maximum, occupied over one third ${ }^{11}$ of the entire area and, in places, were over 3,000 feet thick. Though in part made up of volcanic

1138 per cent. as determined by measurement on an area of 1,870 square miles of the central part of Fig. 52. 
materials, much of the filling is said to have been washed in from the adjacent mountains.

Are we to believe that, after surviving the denudation by which the wide valleys were produced, the mountain areas could supply material for from several hundred to several thousand feet of filling in adjacent basins having a total area over one third as great as that of the mountains themselves and still preserve considerable remnants of the peneplain? All this may be possible, but it is not probable, and the burden of proof is on those who maintain that the basins are the younger.

In reply to a recent criticism by Blackwelder, ${ }^{12}$ Atwood, ${ }^{13}$ in an attempt to prove the post-peneplain age of the basins, cites field evidence which he considers to "be most helpful in this whole discussion, . . ." and to favor the Eocene age of the peneplain, but which seems most decisively against such an age.

On Fig. 52 is shown a system of stream valleys draining southward through what are now passes in the Beaverhead Mountains. The valley crossing Beaverhead range at locality 26 is shown as joining with Lemhi Valley which it receives as a major tributary. The rock bottom of the notch in Beaverhead range is said to lie "at least 500 feet below the old summit peneplain which appears at either side of the pass in the crest of the range." 14

The top of the Miocene beds in Lemhi Valley, at the west foot of the pass referred to, is said and mapped by Umpleby to lie 2,800 feet below the summit peneplain nearby, and the deposits are estimated to be 2,000 feet thick. The rock bottom of the valley in which they lie would, therefore, be 4,800 feet below the summit peneplain. But in the pass, according to Atwood, the rock bottom lies "at least 500 feet," or using the larger figure, I, 300 feet below the peneplain. Thus using the peneplain as a

12 Blackwelder, Eliot, Econ. Geol., Vol. XII., pp. 54I-545, I9I7.

13 Econ. Geol., Vol. XII., pp. 546-547, 1917.

14 In the original paper the somewhat discordant statement is made that the alluvial deposits in this pass are about $I, 000$ feet thick. If this is so, their base may be taken, at a maximum, to be I,300 feet below the summit peneplain. 
datum, the bottom of the main valley, as shown and described by Atwood, is hanging 4,300 feet (or, using the larger figures, 3,500 feet) above the bottom of its tributary. It is inconceivable that valleys as broad as these should not have been at grade when formed. Both valleys are said to have been developed after the formation of the peneplain. Faulting might account for the present discrepancy in elevation of the rock beds of the two valleys, but it cannot account for their discrepancy with respect to the peneplain unless the valleys were cut and the faulting took place before the development of the peneplain. Could there be clearer evidence that, if the basins were ever parts of a stream system, they antedate the formation of the peneplain and that the peneplain is post-Miocene instead of Eocene?

In reply to Blackwelder's criticism, Atwood, ${ }^{15}$ in urging that the peneplain cannot be post-Miocene, cites as evidence Umpleby's determination of Miocene lake shores:

Mr. Umpleby has reported that lake-shore features cut during Miocene times about the margin of Miocene deposits yet remain. This would not be so if the region examined by him had been peneplained after the close of the lake period.

The only evidence of Miocene lake shores which could be found in Umpleby's publications is that which has been previously discussed. The validity of such evidence needs no further comment.

\section{SUMMARY AND CONCLUSIONS.}

The critical point in the determination of the age of the old erosion surface is the question whether the basins in which the Miocene sediments lie were formed, filled, and deformed before or after the peneplain was cut.

A detailed examination of the evidence not only fails to reveal proofs that the peneplain is Eocene, but it brings out many features which point toward the conclusion that the basins in which the Miocene sediments lie were blocked out, filled, and in the 15 Loc. cit., p. 546. 
main, these sediments were deformed before the peneplain was cut.

The date of the peneplain, therefore, is probably late Miocene or Pliocene. Further critical examination in the field is needed before the date can be determined more exactly.

If the peneplain is later than the basins, the dating of the ore deposits of Idaho must be revised, and the series of events in the physiographic history of the Butte District, including those connected with the enrichment of the copper ores, demands an interpretation quite different from that given by Atwood. 